\title{
Female students' experience in preventing scabies
}

\author{
Fithri Iradaty $^{1}$, Edy Suyanto ${ }^{2}$, Budi Aji ${ }^{3}$, Abdal Chaqil Harimi ${ }^{4}$ \\ ${ }^{1,2}$ Master Program on Environmental Science, Jenderal Soedirman University, Purwokerto, Central Java, Indonesia \\ ${ }^{3}$ School of Public Health, Faculty of Health Sciences, Jenderal Soedirman University, Purwokerto, Central Java, \\ Indonesia \\ ${ }^{4}$ Faculty of Education and Teacher Science, State Islamic Institute (IAIN) Purwokerto, Central Java, Indonesia
}

\section{Article Info}

Article history:

Received Jul 16, 2020

Revised May 11, 2021

Accepted Jun 15, 2021

\section{Keywords:}

Environmental health

Islamic boarding school

Scabies

Students' behavior

\begin{abstract}
The purpose of this study was to examine the students' perceptions on the environmental health conditions related to the contagious skin disease of scabies and examine the implementation of clean and healthy behavior of the students. This research was done by adopting qualitative approach with phenomenological method. The qualitative data obtained were analyzed using thematic analysis with the help of the Maxqda 10 Program. The data were collected through purposive and snowball sampling techniques. The findings showed that the environmental sanitation of the Pesantren (Islamic boarding school) in some bedrooms are still not sufficiently ventilated and they needed clean water. The characteristics of Pesantren teaching which teaches students to live modestly, patiently, and prihatin (simple). The perceptions of Pesantren students about scabies that scabies was a normal thing to be experienced by students and that as long as the itching did not produce pus or blood it was not scabies. The healthy behavior of the students in this study were related with taking a bath, maintaining clean clothes, washing hands before eating of the students were still lacking. The efforts in improving the healthy living of the students was seen through the establishment of a health center in the Pesantren called Poskestren (Pesantren Health Services) but there were still limited facilities and the implementation of the administrators' programs to prevent scabies is also seen to be not optimal yet.
\end{abstract}

This is an open access article under the CC BY-SA license.

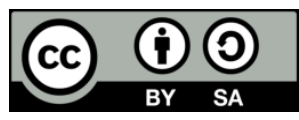

\section{Corresponding Author:}

Fithri Iradaty

Master Program on Environmental Science

Jenderal Soedirman University

Purwokerto, Central Java, Indonesia

Email: fithriiradaty@gmail.com

\section{INTRODUCTION}

Scabies or often called in Indonesia as Gudik is a skin disease caused by the infestation and sensitization of Sarcoptes scabiel var., hominis sp., and their products [1]. The most common symptom of scabies is itching that gets worse at night. Scabies often occurs in people or groups with poor hygiene [2].

Human scabies with prevalence rates that vary depending on the clinical situation is still found in almost all countries in the world [3]. The prevalence rate that occurs worldwide is estimated at 200 million people are affected, with resource-poor tropical areas having a higher prevalence [4]. In some developing countries, the prevalence is reported to be $6-27 \%$ of the population and the highest cases occur in the group of school-age children and young adults. Scabies cases often occur in the group of school-age children with the highest prevalence found in children aged less than 15 years [3]. According to the Ministry of Health of the Republic of Indonesia, the prevalence of scabies in Indonesia in 2008 was, scabies was ranked 3rd of the 
12 most common skin diseases [5]. Based on the health profile of Central Java Province, scabies had emerged as an extraordinary event that infected four sub-districts in Central Java in 2012 [6].

Places with a high population density are vulnerable for scabies transmission, especially Islamic boarding school or Pesantren and dormitories [6]. Pesantren is a joint educational institution between the system of dormitory and Islamic school that provides education and teaching of Islam without grouping students into classes. Pesantrens organize madrasa as a formal education inside the institution in which students learn mainly religious studies and provide pondok for the student's accomodation [7]. The common problem that is often faced by Pesantrens in Indonesia is students' health [8]. According to the study of Romadlon et al. based on 6-month patients records (August 2015-January 2016) in two community health centers in the district of Banyumas, Central Java, Indonesia, there are 11 Pesantrens with scabies cases, and the largest cases are found in three Pesantren namely Pesantren Roudhotut Tholibin Sirau with 42 students infected (35.3\% of the total 119 students), Pesantren Roudhotut Qur'an with 150 students infected (25.9\% of the total 580 students), and Pesantren Nurochman with 20 students infected (10.1\% of the total 198 students) Pesantren Roudhotut Tholibin Sirau, Pesantren Roudhotut Qur'an, and Pesantren Nurochman [9]. Based on the research conducted by Kuspriyanto, the poor environmental sanitary of the Pesantren and the unhealthy behavior of the students contribute to the high prevalence of scabies among them in a Pesantren in Pasuruan, East Java [10]. Similar case was found by Tarigan et al. in a Pesantren in Pati, Central Java as reporting that the poor personal hygiene practices of the students such as unregular bathing, lack of handwashing, unaware of cloth cleanliness, uncleaned bedrooms, and the habit of sharing clothes and towels among them are the main causes of scabies transmission [11].

The research of Chowsidow in the United Kingdom and Baur et al. in India showed that women were more likely to be infected with scabies compared to men with a prevalence of 56\%. [4], [12]. According to the researchers, several factors such as women's preference for staying indoor and their close contacts with others make them more vulnerable to scabies infection [13]. These data are in line with the results of Hapsari's study in 2014 in Indonesia, which showed that women tend to have a higher prevalence of scabies with $62.5 \%$ compared to men with a prevalence of $37.5 \%$ [14].

Based on the above study background, the researchers are interested in conducting further research on the students' behavior toward the environmental health at a Pesantren Karangsuci Purwokerto in regards to scabies. Hopefully, the results of this study could be a reference for health workers, Pesantren communities, and the public in realizing a healthier and more comfortable Pesantren life for the students.

\section{RESEARCH METHOD}

This study used a qualitative method with a phenomenological design. The informants of this study were selected through a purposive sampling method with a criteria-based selection technique, in other words, the informants were selected based on certain criteria and considerations, namely the main target is female students who have or have had scabies and have lived in the Pesantren for at least one year and target support from Pesantren leaders (Kyai or Ustadz) and female student management organizations at Pesantren. In addition to the purposive sampling method, the researchers also used the snowball method in determining the informants. This study was conducted at Pesantren Al Hidayah, Karangsuci, Purwokerto, Indonesia.

The data collection techniques used in this study include observation, structured interviews, and documentation. The data were collected from July to December 2019. The data were analyzed by using thematic analysis with the help of software Maxqda 10 to help coding, processing, and sorting out information in the research process. Thematic analysis is a method for identifying, analyzing, and reporting patterns (themes) contained in the data, and can further interpret various aspects of the research topic [15], [16]. The data were also validated by the data taken from several related parties, namely the leaders of Pesantren Al-Hidayah and other supporting parties such as public health centers and clinics.

Table 1 hows the informants of this study consisted of four female students of Pesantren as main informants, starting with FN as the first informants, then to three other informants consecutively initialized as TS, PFD, and Z. The four informants were in-depth interviewed.

Table 1. Characteristics of main informants

\begin{tabular}{llllll}
\hline No & Initial & Age & \multicolumn{1}{c}{ From } & \multicolumn{1}{c}{ Occupation } & Parent's occupation \\
\hline 1. & FN & 17 y.o. & Banjar, West Java & Undergraduate student & Farmer \\
2. & TS & 19 y.o. & Kebumen, Central Java & Undergraduate student & Textile labor \\
3. & PFD & 19 y.o. & Brebes, Central Java & Undergraduate student & Teacher \\
4. & Z & 19 y.o. & Banyuasin, South Sumatera & Undergraduate student & Farmer \\
\hline
\end{tabular}

Int. J. Public Health Sci., Vol. 10, No. 3, September 2021 : 581 - 589 


\section{RESULTS AND DISCUSSION}

The results of this research are obtained from interviews, observations, and documentation. This study intended to explore the condition of environmental sanitary of Pesantren, the characteristics of Pesantren teaching, the perceptions of Pesantren students about scabies, the healthy behavior of the students, and the efforts and obstacles in improving the healthy living of the students as shown in Table 2 (see in appendix).

\subsection{The condition of the environmental sanitary of Pesantren}

Pesantren has its uniqueness and characteristics with other Pesantren [17]. Alike, Pesantren in this study has special characteristics viewed from it's' environment, the kiai's profile, and the students' characteristics. The environment and the special characteristics of this Pesantren contribute to the health levels of the students.

The Regulation of the Health Minister of the Republic of Indonesia No.173/Men.Kes/Per/VII/1977 stated that water supply must meet the quantity and quality standards, which are safe and hygienic, available in sufficient quantities, and affordable by most people. Referring to this regulation, there are obstacles in fulfilling the needs of clean water for the students at Pesantren, for example when the dry season comes the water-flow decreases, especially during the day, the water flow in very little quantity, sometimes they even do not flow. The study by Fahham suggests that sanitary that meets the health requirements is still a problem for most Pesantren in Indonesia [18]. Fahham's study showed two facts namely the condition of sanitary affects the health of the students, and the sanitary conditions between one Pesantren and the other are different [18].

The sanitary condition of the Pesantren environmental is related to the density of the female students' occupancy. The bedrooms in Pesantren have different ventilation and lighting. Most bedrooms are well ventilated, but some bedroom's ventilation/windows are blocked by hanging clothes (clothes being dried), some bedrooms do not even have ventilation/windows. The data obtained from the observations and interviews conducted by the researchers showed that the bedroom average occupation in Pesantren is \pm 1.9 m2/student. Referring the Decree of the Minister of Settlement and Regional Infrastructure Number 403/KPTS/2002 concerning General Guidelines for Healthy Simple Houses (Rumah Sederhana Sehat ) that the minimum area required for one person to live is nine square meters $(\mathrm{m} 2)$, therefore the density in Pesantren does not meet the standards. This fact is not only found in this Pesantren. Kuspriyanto's study states that the bedrooms provided by a Pesantren in Pasuruan Regency are still not enough with an average density of $1.51 \mathrm{~m} 2 / \mathrm{student}$ per room [10]. Another report was revealed by Astuti as stating that the density at Pesantren Assalafi Al Fithrah Surabaya is $\pm 1.3 \mathrm{~m} 2 /$ student, there are $35-45$ students living in a rooms of 60 $\mathrm{m} 2$ [19].

\subsection{Teaching characteristics of Pesantren}

Some of the regulations of Pesantren are the obligation of Monday and Thursday fastings, the prohibition from carrying cell phones, the permit for going home is given once in a month, the visiting hours for parents, the prohibition from leaving the Pesantren on Sundays except for urgent matters, the schedule of persons in charge of daily cleaning, and weekly ro'an (general cleaning) to clean the Pesantren's environment. These regulations are formulated to teach simplicity, patience, and discipline to the students so that they could cultivate good morals (akhlaqul karimah).

The other characteristics of this Pesantren which affect the health of the students are the education and teaching system of the Pesantren. The discussion on the teaching characteristics of Pesantren is divided into two sub-themes, namely (1) the character education applied by the Pesantren and (2) the discipline habituation imposed to the students. Some characteristics of Pesantren are submission of the students to Kyai, modesty, discipline, and dare to suffer to achieve a goal [17]. These life values are part of the education received by the students in this Pesantren. It has several rules and unique teaching patterns to educate and provide good teaching for its students, including fasting on Monday and Thursday, which teaches students to live modestly, patiently, and prihatin (simple). Fasting is a means of educating human's iradah (will power) so that he/she has a strong will and can be patient in facing temptations, fasting also educates him/her to be tolerant and sensitive to the suffering of others, with the hope that his/her souls are called to help others [20].

The life value teachings at Pesantren are also conveyed through experiences, one of which is $\operatorname{Ro}^{\prime} a n$ which teaches the students to help each other and cooperate. Some of the goals of Ro'an are first, to train the students not to be bakhil (stingy) by donating energy and wealth for Pesantren, a blissful life will be granted to them both during the study at the Pesantren and after graduation when they have to mingle with their community. Second, to cultivate the symbiosis of mutualism relationship between the students and the Pesantren [21]. 


\subsection{The perceptions of Pesantren students about scabies}

The researchers' diagnosis that the diseases suffered by the informants were scabies is based on the characteristics of scabies that are found in these diseases, supported by the diagnosis of the medical staff of IAIN Purwokerto clinic, and further strengthened by the diagnosis of a dermatologist who stated that the diseases suffered by the informants who came to him for treatment were scabies. The informants described the perceptions about scabies among the students in Pesantren. The informants stated that scabies or Gudik is a normal thing to be experienced by santri.

"that (scabies) is a normal thing, before I get enrolled in Pesantren I know that many santri have that (scabies)." (Informant FN, student, December 15, 2019)

The number of mites and the treatment of scabies determines the severity of thescabies disease itself. The number of mites will increase and the symptoms will become more severe if the diagnosis and treatment are delayed [22], [23]. The informants preceived that as long as the itching does not produce pus or blood it is not scabies, in other words, the informants would seek treatment when scabies they experience become severe and disturbing. With such a perception, the informants themselves are sources of infection to the surrounding environment. This is in line with the study of Aminah et al. which stated that scabies cases are highly influented by personal levels of knowledge about scabies [24]. Ramdan et al. also mentioned that there are diseases that commonly happen at Pesantren Modern Assalamah, namely itching and ulcer. The lack of knowledge of the students related to environmental and personal health, the lack of awareness of preventing and understanding the symptoms of the disease, and the density of the Pesantren cause the students to have unhealthy behavior [25].

\subsection{The healthy behaviors of the students of Pesantren}

One of activities to keep the Pesantren's environment healthy is waste management. Waste piles come from the students' bedrooms; they are scheduled to throw them by turns to the temporary waste bin. The wastes then are picked by dump trucks every two or three days.

The students' healthy behaviors on the personal hygiene sub-theme in this study were related to bathing habits, habits in maintaining clean clothes, habits in how to dress up, habits to wash hands before eating, habits to dry personal belongings, and the fulfillment of their nutrition. In maintaining their daily personal hygiene, the students used to bath twice a day, in the morning and evening. The informants conveyed obstacles that were often experienced for bathing, including queues, which were very commonly found in Pesantrens, and the water supply that sometimes flowed very little during the dry season. These conditions are described in the interview excerpt:

"I usually take a bath twice, but usually depends on the water supply, sometimes the water doesn't fill up the tubs, so one bucket, I think is enough." (Informant FN, student, December 15, 2019)

The results of this study related to personal hygiene showed that the informants used to take a bath twice a day in the morning and evening. Some informants expressed the obstacles they experienced to take a bath, including queues that had become a tradition of Pesantren apparently and small flowing water during the dry season. Bathing twice is very important to prevent scabies, because when bathing, mites that are on the surface of the skin will be washed away by water [26], [23]. The results of Akmal's study mentioned that the increased cases of infectious skin disease scabies have a relationship with the levels of personal hygiene awareness [27].

Based on the interviews and observations, the informants had the habit of putting the laundry into a bucket first and leave them for some times before washing them. Besides, their way of dressing was also of concern to the researchers; the informants are accustomed to wearing double-layered clothing even in hot weather which can make the informants more at risk of experiencing scabies.

The informants' poor personal hygiene like the habit of piling up and leaving dirty clothes in a bucket for a long time, rarely ironing clothes, putting clean clothes close to dirty clothes, and drying clothes not under direct sunlight allows transmission of scabies. In preventing scabies transmission according to Sungkar heat from electric irons and sunlight can kill mites that cause scabies if exposed in sufficient time [24]. Hence, not ironing the clothes will let the mites that might stay in the informant's clothing alive, which in turn causes the process of scabies pathogenesis.

The next personal hygiene that comes to the researchers' concern is the habit of washing hands. The interview results showed that most informants were not accustomed to wash their hands in running water and using soap, there were even some who rarely washed their hands before eating. This condition is illustrated in the following interview excerpts: 
“I rarely wash my hands, (hehe).” (Informant Z, student, 23 December 2019)

Of the four main informants who had had or were having scabies, three stated that they got infected with scabies from the contacts with their roommates. Some habits of the students that cause scabies transmission are the habit of sharing one another's personal belongings such as veils, jackets, and towels, the habit of sleeping together in one bed, and intense physical contact.

In addition to the personal hygiene factors, scabies can also be transmitted directly or indirectly. The movement of larvae, eggs, nymphs, or mites of S. scabies from the skin of patients to other people's skin either directly or indirectly can cause scabies transmission [23]. The habit of some students at Pesantren to sleep together in one mattress can cause direct scabies transmission, meanwhile their habit to share their personal belongings can cause indirect transmission. The study of Ma'rufi et al. stated that the students' behavior such as sharing personal belongings and sleeping together in one bed will result in a greater likelihood of being exposed to scabies. Some students stated that these habits are not forms of bad behavior, they are forms of friendship among them [28].

\subsection{The efforts and obstacles in improving the healthy living of the students}

Various efforts have been carried out by Ibu Nyai, Ndalem, the administrators, and the students in improving the health level of the students, especially in the context of preventing scabies. For example, Ibu Nyai and the administrators formulated a set of regulations in keeping the cleanliness of the environment, also schedules in every unit of the entire Pesantren area. Besides, messages of keeping healthy and clean living have also been conveyed to the students through religious teachings, Ibu Nyai and the figures of Pesantren often give appeals and direction to the students to always maintain the cleanliness and tidiness of the Pesantren's environment in their teaching sessions.

The efforts to prevent scabies as explained above encountered various obstacles both external and internal. Among the external obstacles is the lack of education and promotion about scabies presented to the students by Puskesmas (Public Medical Centers). Meanwhile, the internal obstacles in scabies prevention are, among others, the system of checking sick students carried out by the administrators need to be improved, administrators tend to pay more attention to students who suffer from illnesses that are claimed to be more serious, scabies is seen as an ordinary disease. The implementation of the administrators' programs to prevent scabies is also seen to be not optimal yet. Besides, the activities of students in preventing the spread of scabies and maintaining environmental health need to be more improved.

The principals, administrators, and students of Pesantren have made various efforts to maintain environmental health inpreventing scabies. According to Widyarini and Rohmah in 2014 the charisma of a Pesantren principal has special meanings for students and those who will sign up for the Pesantren. Ibu Nyai Nadhiroh as the principal of Pesantren for females has high charisma for her enthusiasm in educating the students [29]. Khotimah also expressed in her study that Ibu Nyai is a charismatic figure of a female leader [30].

The role of leaders in eradicating scabies is seen through the establishment of a health center in the Pesantren called Poskestren (Pos Kesehatan Pesantren). Wahyudin and Arifin stated that the Poskestren in this Pesantren is expected to be able to empower the students in maintaining personal and environmental health [31]. However, there were internal and external obstacles in maintaining the health of the Pesantren environment, one of which was the carelessness of the students to maintaining healthy living, in line with the case revealed by Ramdan in Pesantren Assalamah where the majority of the students are still being careless to maintain a healthy life and prevent the emergence of diseases that can harm them [25].

\section{CONCLUSION}

The students perceived that maintaining environmental health is very important to keep anyone from contracting diseases including scabies. However, on the other hand, the students also perceived that it has become normal for them to experience scabies and have an untidy environment. Pesantrens are commonly perceived as being overcrowded so that the informants found it difficult to maintain the cleanliness and tidiness of the Pesantren's environment. The personal hygiene behavior of the female students such as taking a bath, washing hand, drying clothes, and the fulfillment of their nutrition still need to be improved.

\section{ACKNOWLEDGEMENTS}

We thank the Pesantren Al Hidayah Karangsuci Purwokerto for willingness to be a research location for this study and Master Program on Environmental Health, Jenderal Soedirman University, Purwokerto, Indonesia as a supported of this research. Most of all, we thank to the study informant. 


\section{REFERENCES}

[1] R. Boediardja and SA., Handoko, "Dermatology and Venereology (In Indonesia: Ilmu Penyakit Kulit dan Kelamin)," VII. Jakarta: FK UI, 2016.

[2] Mutiara H., Syailindra F., "Scabies" (In Indonesia: Skabies)" Majority, vol.5, no.2, pp. 37-42, 2016.

[3] Chandler, D.J., Fuller, L.C., "A Review of Scabies: An Infection More than Skin Deep" Dermatology, 235, pp. 7990, 2019.

[4] Karimkhani C., et al., "The Global Burden of scabies: a cross-sectional analysis from the Global Burden of Disease Study 2015," Lancet Infect Dis. vol. 17, no. 12, pp. 1247-1254, 2017.

[5] Tarigan et al., "The Effect of Personal Hygiene on the Prevalence of Scabies in the Matholiul Huda Al Kautsar Pesantren, Pati (In Indonesia: Pengaruh Higiene Perorangan terhadap Prevalensi Terjadinya Penyakit Scabies Di Pondok Pesantren Matholiul Huda Al Kautsar Kabupaten Pati)," Diponegoro Medical Journal, vol. 7, no. 1, pp. 113-126, 2018.

[6] Pratama T.S., Septianawati P., Pratiwi H., "Knowledge, Attitudes, Personal Hygiene and Habits in Students of Scabies Diseases in Pondok Pesantren (In Indonesia: Pengetahuan, Sikap, Kebersihan Personal dan Kebiasaan pada Santri Penderita Penyakit Skabies di Pondok Pesantren)," Scientific Journal of Health Sciences, vol. 15, no. 3, pp. 173-178, 2017.

[7] Alwi B. M., "Pondok Pesantren: Characteristics, Development, and Education System (In Indonesia: Pondok Pesantren: Ciri Khas, Perkembangan dan Sistem Pendidikannya)," Lentera Pendidikan, vol. 16, no.2, pp. 205-219, 2013.

[8] Ikhwanudin A., "Santri Health Behavior: Descriptive Study of Health Care Behavior, Search and Use of the Health System and Environmental Health Behavior in Assalafi Al Fithrah Pesantren, Surabaya (In Indonesia: Perilaku Kesehatan Santri: Studi Deskriptif Perilaku Pemeliharaan Kesehatan, Pencarian Dan Penggunaan Sistem Kesehatan Dan Perilaku Kesehatan Lingkungan Di Pondok Pesantren Assalafi Al Fithrah, Surabaya)," Political and Sociology Journal, vol. 1, no. 2, 2011.

[9] Kuspriyanto, "The Effects of Environmental Sanitation and Santri's Healthy Behavior on Scabies Occurrence in Islamic Boarding Schools in Pasuruan Regency, East Java (In Indonesia: Pengaruh Sanitasi Lingkungan dan Perilaku Sehat Santri terhadap Kejadian Skabies di Pondok Pesantren Kabupaten Pasuruan Jawa Timur)," Journal of Geography, vol. 11, no. 21, pp. 64-73, 2013.

[10] Romadlon S., Hilal N., Lagiono, "The Relationship between Personal Hygiene practices and the condition of Kemranjen Banyumas sub-district in 2016 (In Indonesia: Hubungan Praktik Personal Hygiene dan Kondisi Sanitasi Lingkungan Dengan Kejadian Skabies pada Santri Di Pondok Pesantren Roudhotut Tholibin Sirau Kecamatan Kemranjen Kabupaten Banyumas Tahun 2016)," Journal of Environmental health. Politek. Kesehat. Kemenkes Semarang, 2016.

[11] Vica C. et al., "Effects of Individual Hygiene on the Prevalence of Scabies in the Matholiul Huda Al Kautsar Islamic Boarding School in Pati Regency (In Indonesia: Pengaruh Higiene Perorangan Terhadap Prevalensi Terjadinya Penyakit Scabies di Pondok Pesantren Matholiul Huda Al Kautsar Kabupaten Pati)," Journal of Medicine Diponegoro, vol. 7, no. 1, pp. 113-126, 2018.

[12] Baur D.B., "The Pattern of Dermatological Disorders among Patients Attending the Skin O.P.D of A Tertiary Care Hospital in Kolkata, India," IOSR J. Dent. Med. Sci., vol. 3, pp. 1-6, 2013.

[13] Nuraini N., and Wijayanti R.A., "Relationship between Sex and Level of Knowledge with the Incidence of Scabies in Islamic Boarding School Nurul Islam Jember (In Indonesia: Hubungan Jenis Kelamin dan Tingkat Pegetahuan dengan Kejadian Skabies di Pondok Pesantren Nurul Islam Jember)," Journal of Research and Community Service BOPTN Funding Seminar 2016, pp. 42-47, 2016.

[14] Ibadurrahmi H., Veronica S., Nugrohowati N., "Factors that Influence the Occurrence of Scabies Disease in Santri at Qotrun Islamic Boarding School Cipayung Depok (In Indonesia: Faktor-Faktor yang Berpengaruh terhadap Kejadian Penyakit Skabies pada Santri di Pondok Pesantren Qotrun Nada Cipayung Depok Februari Tahun 2016)," Medical Journal and Professional Journal., vol. 10, no. 1, pp. 33-45, 2017.

[15] Junaid, I., "Qualitative Data Analysis in Tourosm Research"(In Indonesia: Analisis Data Kualitatif dalam Penelitian Pariwisata), Jurnal Kepariwisataan, vol. 10, no.1, pp. 59-74, 2016.

[16] Heriyanto, H., "Thematic Analysis as a method of analyzing data for Qualitatif Research (In Indonesia: Thematic Analysis sebagai Metode Menganalisa Data untuk Penelitoan Kualitatif )," Journal Anuva, vol. 2, no. 3, pp. 317 324, 2018.

[17] Hafidh Z. et al., "The Role of Kiai Leadership and Character Education: A Pattern of Santri Character Formation at Asy-Syifa Al-Qur'an Islamic Boarding School." Journal of Leadership in Organizations, vol.1, no.2, 2019.

[18] Fahham, A.M., "Sanitation and its Impact on Health Studies from Islamic Boarding Schools (In Indonesia: Sanitasi dan Dampaknya bagi Kesehatan Studi dari Pesantren)," J. Aspirasi, vol. 10, no. 1, pp. 33-47, 2019.

[19] Astuti N., "The Relationship between Santri's Behavior and Physical Environmental Conditions and the Occurrence of ARI in Assalafi Al-Fithroh Islamic Boarding School in Surabaya (In Indonesia: Hubungan Perilaku Santri dan Kondisi Lingkungan Fisik dengan Kejadian ISPA di Pondok Pesantren Assalafi Al-Fithroh Surabaya)," Environmental Health Journal, vol. 10, no. 2, pp. 233-242, 2018.

[20] Maksudin, "Integration of School and Pesantren Educational System as a Model of Character Education : Perspective of educational Transformation," International Journal on Islamic Educational Research (SKIJIER), vol.2, no. 1, pp. 32-59, 2018.

[21] Ibrahim R., "Pesantren and Community Service: Case Study of Dawar Boyolali Islamic Boarding School in Central Java (In Indonesia: Pesantren dan Pengabdian Masyarakat: Studi Kasus Pondok Pesantren Dawar Boyolali Jawa 
Tengah)," Jurnal Al Tahrir, vol. 16, no. 1, pp. 89-108, 2016.

[22] Banerji A., "Canadian Paediatric Society, First Nations, Inuit and Metis Health Committee Skabies," Paediatr Child Health, vol.20, no.7, pp. 395-402, 2015.

[23] Sungkar P.S., "Scabies: Etiology, Pathogenesis, Treatment, Eradication and Prevention (In Indonesia: Skabies: Etiologi, Patogenesis, Pengobatan, Pemberantasan dan Pencegahan)," Jakarta: Fakultas Kedokteran Universitas Indonesia, 2016.

[24] Aminah P., Sibero H.T., Ratna M.G., "Relationship between Knowledge Level and Scabies Occurrence (In Indonesia: Hubungan Tingkat Pengetahuan dengan Kejadian Skabies)," Jurnal Majority, vol. 4, no.5, pp. 54-59, 2015.

[25] Ramdan A.A., Iswari, Wijaya, "Patterns of Santri Disease in Assalamah Modern Islamic Boarding School (In Indonesia: Pola Penyakit Santri di Pondok Pesantren Modern Assalamah)," Journal of Education, Society, and Culture, vol. 2, no. 1, pp. 1-8, 2013.

[26] Midlleton J., "Scabies control: the forgotten role of Personal Hygiene," Lancet Infect Dis, vol.18, pp. 1068-1069, 2018.

[27] Akmal S.C., Semiarty Gayatri, "The Relationship of Personal Hygiene with the Occurrence of Scabies at Darul Ulum Islamic Education, Palarik Air Pacah, Koto Tangah Padang in 2013 (In Indonesia: Hubungan Personal Hygiene dengan Kejadian Skabies di Pondok Pendidikan Islam Darul Ulum, Palarik Air Pacah Kecamatan Koto Tangah Padang)," Health Journal Andalas, vol. 2, no. 3, pp. 164-167, 2013.

[28] Ma'rufi I., Istiaji E., Witcahyo E., "The Relationship between Santri's Healthy Behavior and the Scabies Occurrence in the Lamongan Islamic Boarding School (In Indonesia: Hubungan Perilaku Sehat Santri dengan Kejadian Scabies di Pondok Pesantren Kabupaten Lamongan)” IKESMA, vol. 8, no. 2, pp. 119-129, 2012.

[29] Widyarini, and Rohmah, M., "Influence of Perception of Cost, Location, Facilities, Environment, Caregiver Figure, and Learning Methods on Satisfaction of Santri Living in Pesantren (In Indonesia: Pengaruh Persepsi Biaya, Lokasi, Fasilitas, Lingkungan, Figur Pengasuh, dan Metode Belajar terhadap Kepuasan Santri Tinggal di Pondok Pesantren)," Az Zarqa, vol. 6, no.1, pp. 37-65, 2014.

[30] Khotimah K., "The Role of Mrs. Nyai's Leadership in Managing Pesantren: A Case Study of Al Hiadayah Islamic Boarding School Putri Karangsuci Purwokerto Utara (In Indonesia: Peran Kepemimpinan Bu Nyai Dalam Memanajemen Pesantren: Studi Kasus Pesantren Al-Hidayah Putri Karang Suci Purwokerto Utara)" Relogious Journal, vol. 18, no. 2, pp. 337-355, 2017.

[31] Wahyudin U., and Arifin, "Socialization of Self and Environmental Sanitation in Salafi Pesantren through Pesantren Health Posts in Forming Santri Attitudes towards Sanitation (In Indonesia: Sosialisasi Sanitasi Diri dan Lingkungan di Pesantren Salafi Melalui Pos Kesehatan Pesantren (Poskestren) dalam Membentuk Sikap Santri terhadap Sanitasi)," J. Kaji. Komun., vol. 3, no. 2, pp. 148-153 2015.

\section{APPENDIX}

Table 2. Steps of thematic analysis framework

\begin{tabular}{|c|c|c|c|c|}
\hline $\begin{array}{l}\quad \text { Codes } \\
\text { Pesantren's } \\
\text { water sources } \\
\text { Water's } \\
\text { characteristics }\end{array}$ & $\begin{array}{l}\text { Issue discussed } \\
\text { clean water is supplied from wellbores } \\
\text { sometimes, the water flows in small quantity, } \\
\text { sometimes it even stops flowing at the } \\
\text { daylight especially in the dry season }\end{array}$ & $\begin{array}{l}\text { Basic/initial theme } \\
\text { Pesantren's water } \\
\text { sources } \\
\text { the Pesantren's water } \\
\text { characteristics }\end{array}$ & $\begin{array}{l}\quad \text { Organizing/ } \\
\text { Developed theme } \\
\text { students' clean } \\
\text { water needs }\end{array}$ & $\begin{array}{l}\text { Global/final } \\
\text { theme } \\
\text { the condition of } \\
\text { environmental } \\
\text { sanitary of } \\
\text { Pesantren }\end{array}$ \\
\hline $\begin{array}{l}\text { Students' } \\
\text { drinking water }\end{array}$ & all students drink from gallon water & $\begin{array}{l}\text { students' drinking water } \\
\text { sources }\end{array}$ & & \\
\hline $\begin{array}{l}\text { Population } \\
\text { density }\end{array}$ & $\begin{array}{l}\text { the occupant density in each of the students' } \\
\text { bedrooms }\end{array}$ & the density in bedrooms & $\begin{array}{l}\text { the condition of } \\
\text { students' }\end{array}$ & \\
\hline $\begin{array}{l}\text { Bedroom } \\
\text { ventilation }\end{array}$ & bedroom ventilation & $\begin{array}{l}\text { the condition of } \\
\text { bedroom ventilation }\end{array}$ & bedrooms & \\
\hline $\begin{array}{l}\text { Bedroom } \\
\text { condition }\end{array}$ & the bedroom lighting & & & \\
\hline Tirakat (penance) & students are obliged to do Monday and & religious teaching for & Pesantren's & the \\
\hline activity & Thursday fasting as good nurturing activities & the students & character & characteristics \\
\hline Modesty & the teaching to live a modest and patient life & the cultivation of & education & of Pesantren \\
\hline Mutual assistance & $\begin{array}{l}\text { life full with tolerance and mutual assistance } \\
\text { among the students }\end{array}$ & akhlakul karimah & & teaching \\
\hline Regulation & $\begin{array}{l}\text { takzir (punishment) in the forms of cleaning } \\
\text { the environment }\end{array}$ & Pesantren's regulation & $\begin{array}{l}\text { discipline } \\
\text { instilment to the } \\
\text { students }\end{array}$ & \\
\hline Defining scabies & $\begin{array}{l}\text { Gudik or scabies is a common disease } \\
\text { infecting santri (Pesantren students) } \\
\text { santri got infected with scabies due to the } \\
\text { habit of sharing personal belongings which is } \\
\text { a common practice among santri }\end{array}$ & $\begin{array}{l}\text { the perception that } \\
\text { scabies is a common } \\
\text { disease for santri }\end{array}$ & $\begin{array}{l}\text { perceptions on } \\
\text { scabies }\end{array}$ & $\begin{array}{l}\text { the perceptions } \\
\text { of Pesantren } \\
\text { students about } \\
\text { scabies }\end{array}$ \\
\hline $\begin{array}{l}\text { The } \\
\text { environmental } \\
\text { health }\end{array}$ & $\begin{array}{l}\text { informants infected with the disease see that } \\
\text { the environmental health is very important }\end{array}$ & $\begin{array}{l}\text { the view on maintaining } \\
\text { the environmental } \\
\text { health }\end{array}$ & $\begin{array}{l}\text { the perception of } \\
\text { environmental } \\
\text { health }\end{array}$ & \\
\hline The cleanliness & the cleanliness of bathrooms is determined by & & & \\
\hline
\end{tabular}




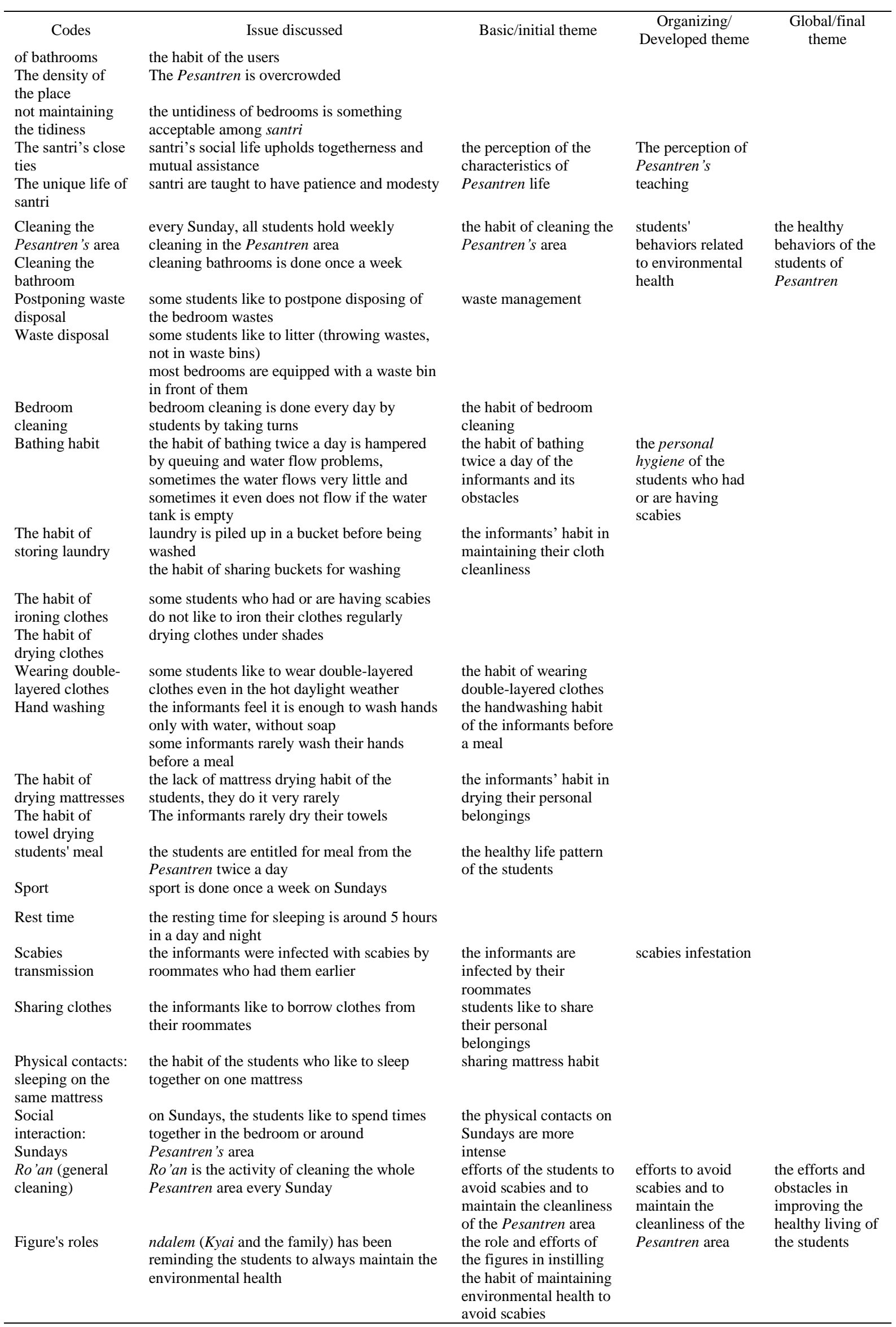




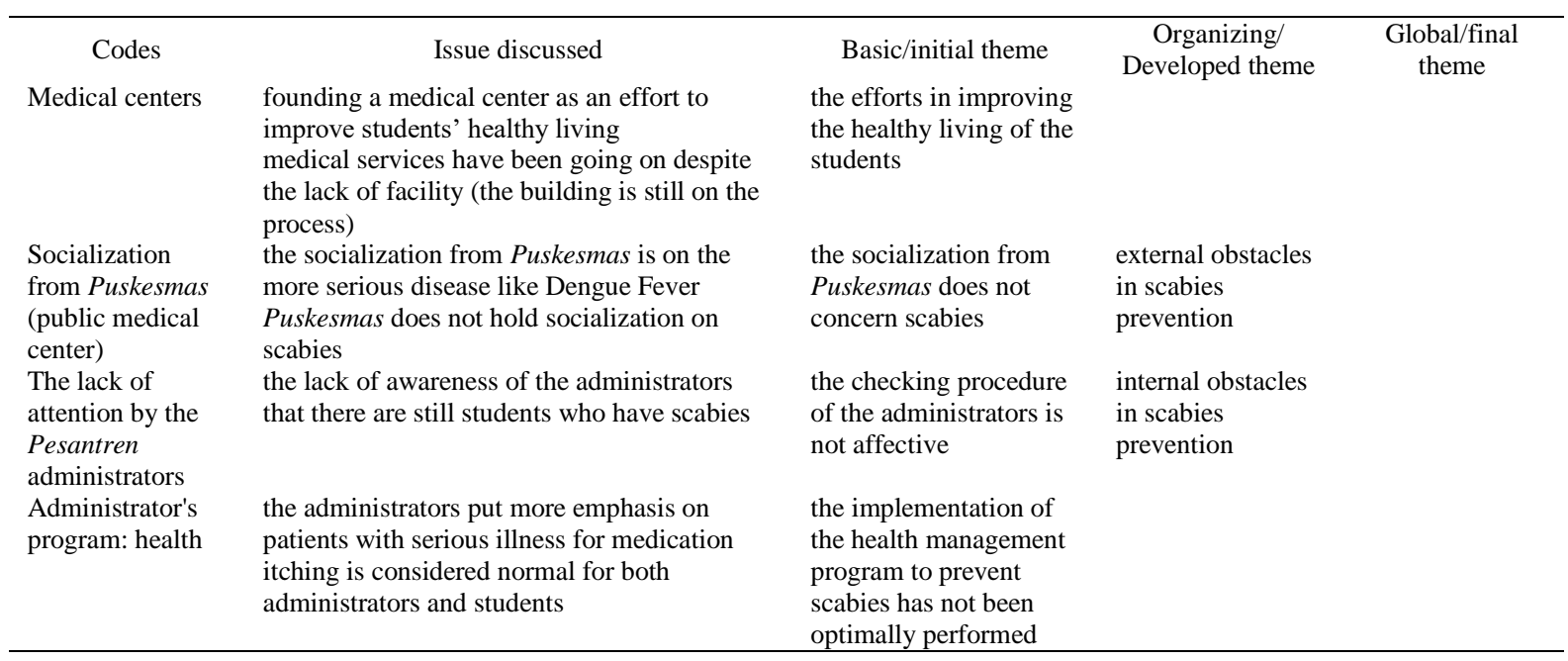

